\title{
POTENSI WISATA KULINERI DAN PENDIDIKAN DI PESONA ALAM DUSUN SENDANG KUMITIR DESA KEMBANG ARUM , TURI, SLEMAN SEBAGAI DAERAH TUJUAN WISATAWAN
}

\author{
Wisnu Hadi \\ NIDN 0505067501 \\ wisnu.wsh@bsi.ac.id \\ Dosen Akademi Pariwsata BSI Yogyakarta
}

\begin{abstract}
One of the tourism products in Yogyakarta which is now again a trend and developed is educational tours and culinary tours that can complement other tours such as natural attractions and culture. Because the natural and cultural tourism products are very much in Yogyakarta. A lot of information from the print and electronic media that interest tourism such as culinary and education are widely sold in the media because it is very promising income and certainly increase the regional economic income. One of the educational and culinary tour is the Natural Enchantment Sendang Kumitir Hamlet that has the potential of culinary tourism and education. In this qualitative descriptive research the researcher exposed about the potential that support the tourism. SWOT analysis also explained that this tour should be developed by managers to be bigger because there is still enough land to expand the tour. From the results of the questionnaire data that tourists are enjoying the education and culinary tour because it is supported by the natural atmosphere that is still beautiful and cool because in the middle of the village and surrounded by bark garden is quite wide. In terms of service to tourists considered satisfactory in terms of attractiveness, facilities and human resources or managers in this case employees and owners of these attractions
\end{abstract}

\section{PENDAHULUAN}

Kabupaten Sleman di Provinsi Yogyakarta sangat kaya akan alam dan kulinerinya untuk dikunjungi wisatawan domestik dan asing. Hal ini terbukti dengan banyak wisatawan yang berkunjung didaerah-daerah yang memiliki potensi alam yang indah dan sejuk serta ramah penduduknya. Setiap liburan panjang seperti akhir tahun dan hari raya agama serta cuti bersama wisatawan banyak yang membanjiri lokasi wisata tersebut.

Seiring dengan berkembangnya bisnis dan invesrasi akomodasi di Yogyakarta, variasi data tarik wisata dan destinasi baru perlu untuk dikembangkan sehingga dapat menarik wisatawan. Jumlah wisatwan (domestik dan mancanegara) yang mengunjungi Yogyakarta pada kurun 2005 hingga 2010 hanya meningkat 1,36\% dari 1.070.937 pada 2005 menjadi 1.456 .980 di tahun 2010 (Dinas Pariwisata DIY, 2010 \& 2011). Dengan angka seperti itu maka perlu strategi pengembangan pariwisata yang kongkrit dari semua stakeholders seperti pemerintah, swasta dan masyarakat.

Salah satu produk wisata di Yogyakarta yang sekarang lagi trend dan dikembangkan adalah wisata pendidikan dan wisata kuliner yang bisa melengkapi wisata lain seperti wisata alam dan budaya. Karena produk wisata alam dan budaya sudah sangat banyak di Yogyakarta. Banyak informasi dari media cetak dan elektronik bahwa wisata minat seperti kuliner dan pendidikan banyak dijual dimedia karena sangat menjanjikan pendapatan dan tentunya meningkatkan pendapatan ekonomi daerah.

Warga masyarakat di Sleman sekarang mulai menyadari bahwa daerah atau wilayahnya mempunyai aset yang dapat mendatangkan wisatawan sehingga akan memberi dampak ekonomi wilayahnya khususnya warganya. Mereka sadar bahwa potensi wisata di Sleman ternyata masih banyak belum di gali, seperti wisata kulineri yang selalu dicari oleh wisatawan ketika berkunjung ke daerahnya.

Salah satu daerah yang mempunyai potensi wisata pendidikan dan kulineri adalah di Dusun Kembangarum XV Balong Kelurahan Donokerto kecamatan Turi Kabupaten Sleman Daerah Istimewa Jogjakarta yang terkenal dengan Pesona Alam Dusun Sendang Kumitir. Wisata yang telah dibuka sejak tahun 2010 ini semakin hari semakin ramai. Potensi alam yang mendukung wisata kulineri dan pendidikan ini patut dikembangkan karena sangat menarik wisatawan yang suka kulineri dan pendidikan alam.

Peneliti sangat tertarik untuk meneliti potensi yang ada didaerah tersebut sehingga melakukan penelitian tentang Potensi Wisata Kulineri dan Wisata Pendidikan Pesona Alam Dusun Sendang Kumitir Dusun Kembangarum XV Balong Kelurahan Donokerto kecamatan Turi Kabupaten Sleman. Tentunya peneliti akan menganalisa kelebihan, kekurangan, peluang dan ancaman terhadap wisata tersebut. Selain itu melihat penilaian dari para wisatawan yang berkunjung ditersebut.

\section{LITERATURE REVIEW}

\section{Pariwisata}

Arti "pariwisata” belum banyak diungkapkan oleh para ahli bahasa dan pariwisata Indonesia. Kata "pariwisata" berasal dari dua suku kata, yaitu pari dan wisata. Pari berarti banyak, berkali-kali dan berputar- 
putar, sedangkan wisata berarti perjalanan atau bepergian yang dilakukan secara berkali-kali atau berkeliling.

Pariwisata menurut Gamal Suwantoro (1997) Istilah pariwisata berhubungan erat dengan pengertian perjalanan wisata yaitu sebagai suatu perubahan tempat tinggal sementara seseorang diluar tempat tinggalnya karena suatu alasan dan bukan untuk melakukan kegiatan yang menghasilkan upah .

Pariwisata menurut Nyamon S. Pendit (2006), adalah salah satu jenis industri baru yang mampu memperrcepat pertumbuhan ekonomi dan penyediaan lapangan kerja, peningkatan penghasilan, standar hidup serta menstimulasi sektor-sektor produktif lainnya. Menurut Pendit, pariwisata telah dikenal menjadi beberapa jenis antara lain:

1. Wisata budaya

2. Wisata konvensi

3. Wisata kesehatan

4. Wisata bulan madu

5. Wisata olahraga

6. Wisata industri

7. Wisata alam

8. Wisata komersial

9. Wisata ziarah

10. Wisata buru

Sedangkan motif orang melakukan perjalanan wisata ada bermacam-macam tergantung apa yang diinginkan oleh wisatawan, antara lain:

1. Motif bersenang-senang

2. Motif rekreasi

3. Motif kebudayaan

4. Motif spiritual

5. Motif kesehatan

Menurut Undang-undang Republik Indonesia Nomor 10 Tahun 2009 tentang kepariwisataan, daya tarik wisata adalah segala sesuatu yang memiliki keunikan, keindahan dan nilai yang berupa keanekaragaman kekayaan alam, budaya dan hasil buatan manusia yang menjadi sasaran atau tujuan kunjungan wisatawan. Keadaan alam, flora dan fauna, sebagai karunia Tuhan Yang Maha Esa, serta peninggalan purbakala, peninggalan sejarah, seni dan budaya yang dimiliki bangsa Indonesia merupakan sumber daya dan modal pembangunan kepariwisataan untuk peningkatan kemakmuran dan kesejahteraan rakyat sebagaimana terkandung dalam pancasila dan pembukaan Undang-undang Dasar Republik Indonesia Tahun 1945.

Menurut Yoeti (2006:55-56) Daya tarik wisata dibagi menjadi empat bagian yaitu;

1. Daya tarik wisata alam, yang meliputi pemandangan alam, laut, pantai dan pemandangan alam lainnya.

2. Daya tarik wisata dalam bentuk bangunan, yang meliputi bersejarah dan modern, monumen, peninggalan arkeologi, lapangan golf, toko dan tempat perbelanjaan lainnya.

3. Daya tarik wisata budaya yang meliputi sejarah, faktor, agama, seni, teater, hiburan dan museum.

4. Daya tarik wisata sosial, yang meliputi cara hidup masyarakat setempat, bahasa, kegiatan sosial masyarakat, fasilitas dan pelayanan masyarakat.

2. Strategi

Menurut Hamel dan Prahald (Muljadi, 2006: 29), strategi merupakan tindakan yang bersifat incremental (senantiasa meningkat) dan terus-menerus,

yang dilakukan berdasarkan sudut pandang tentang apa yang diharapkan oleh para pelanggan organisasi di masa depan.

Salah satu pengertian Manajemen Strategik adalah proses atau rangkaian kegiatan pengambilan keputusan yang bersifat mendasar dan menyeluruh, disertai penetapan cara melaksankannya, yang dibuat oleh manajemen puncak dan diimplementasikan oleh seluruh jajaran di dalam suatu organisasi, untuk mencapai tujuannya (Nawawi 2000 : 148).

Ada beberapa manfaat yang dikemukakan oleh Wahyudi (1996:19) bagi organisasi yang menerapkan Manajemen Strategik, yaitu :

1. Memberikan arah jangka panjang yang akan dituju.

2. Membantu organisasi beradaptasi pada perubahanperubahan yang terjadi.

3. Membuat suatu organisasi menjadi lebih efektif.

4. Mengidentifikasikan keunggulan komparatif suatu organisasi dalam lingkungan yang semakin beresiko.

5. Keterlibatan karyawan dalam pembuatan strategi untuk lebih memotivasi mereka pada tahap pelaksanaanya.

\section{Pengertian Pemasaran}

Pemasaran adalah suatu proses sosial dan manajerial dengan mana individu-individu dan kelompok mendapatkan apa yang mereka butuhkan dan inginkan melalui penciptaan, penawaran, dan pertukaran produk-produk yang bernilai (Kotler, 2005: 5). Definisi pemasaran itu berpijak pada konsep-konsep inti pemasaran, yakni sebagai berikut :

1. Kebutuhan, keinginan dan permintaan

2. Produk

3. Nilai biaya dan kepuasan

4. Pasar

5. Pertukaran transaksi dan hubungan

Menurut Sumarni (2002: 261) pemasaran adalah suatu sistem keseluruhan dari kegiatan bisnis yang ditujukan untuk merencanakan, menentukan harga, mempromosikan dan mendistribusikan barang dan jasa yang memuaskan kebutuhan, baik kepada pembeli yang ada maupun pembeli potensial.

\section{Marketing Mix}

Marketing mix adalah kombinasi dari empat variabel/kegiatan yang merupakan inti dari sistem 
pemasaran yaitu, produk, harga, promosi, dan distribusi. Atau dengan kata lain, marketing mix merupakan kumpulan variabel-variabel yang dapat digunakan oleh perusahaan untuk mempengaruhi tanggapan konsumen.

Keempat variabel strategi acuan/baur pemasaran tersebut adalah:

1. Strategi produk

2. Strategi harga

3. Strategi penyaluran (distribusi)

4. Strategi promosi

Bauran promosi menurut Kotller (2009) merupakan penggabungan dari lima model komunikasi dalam pemasaran, yaitu :

a) Iklan (advertising) : Setiap bentuk presentasi yang bukan dilakukan orang dan promosi gagasan, barang, atau jasa oleh sponsor yang telah ditentukan. b) Promosi Penjualan (Sales Promotio) : Berbagai jenis insentif jangka pendek untuk mendorong orang mencoba atau membeli produk atau jasa.

c) Hubungan masyarakat dan pemberitaan (Public realton and Publicity ): Berbagai program yang dirancang untuk mempromosikan atau melindungi citra perusahaan atau masing-masing produknya.

d) Penjualan pribadi (Personal Selling) : Interaksi tatap muka dengan satu atau beberapa calon pembeli dengan maksud untuk melakukan presentasi, menjawab pertanyaan, dan memperoleh pemesanan.

e) Pemasaran langsung dan interaktif (Direct and Interactive Selling): Penggunaan surat, telepon, faksimili, e-mail, atau internet untuk berkomunikasi langsung atau meminta tanggapan atau berdialog dengan pelanggan tertentu dan calon pelanggan.

Table .1. Bauran Promosi

\begin{tabular}{|l|l|}
\hline \multicolumn{1}{|c|}{ Bauran Promosi } & \multicolumn{1}{c|}{ Media } \\
\hline Iklan (advertising) & $\begin{array}{l}\text { Elektronik seperti : televisi dan radio } \\
\text { Cetak seperti : koran, majalah, brosur, spanduk, } \\
\text { poster, baliho }\end{array}$ \\
\hline $\begin{array}{l}\text { Hubungan Masyarakat } \\
\text { dan Publikasi (Public } \\
\text { relation \& publicity) }\end{array}$ & $\begin{array}{l}\text { Menyelenggarakan kegiatan (events) seperti : } \\
\text { lomba musik, ada sponsor. } \\
\text { Pelatihan seni untuk pemerintah gratis } \\
\text { Seminar }\end{array}$ \\
\hline $\begin{array}{l}\text { Pemasaran langsung } \\
\text { (Direct selling) }\end{array}$ & $\begin{array}{l}\text { Menggunakan surat, telepon dan media lain untuk } \\
\text { berkomunikasi secara langsung dengan masyarakat } \\
\text { pencinta seni. }\end{array}$ \\
\hline
\end{tabular}

Setiap elemen dalam bauran promosi dapat dilaksanakan oleh organisasi dalam mengkomunikasikan produk kreasi seni dan layanan yang baik kepada masyarakat. Penggunaan beberapa bauran promosi dapat lebih meningkatkan efektifitas komunikasi dalam memasarkan produk kreasi seni dan jasa kepada masyarakat.

Dalam pariwisata sering dikenal istilah promosi pariiwisata yang merupakan bagian dari strategi pemasaran karena itu sarana mengenalkan obyek wisata atau tempat wisata. Menurut Menurut Oka A. Yoeti (2005:169), promosi wisata adalah bentuk penyampaian informasi dan meyakinkan kepada wisatawan ataupun calon wisatawan tentang potensi menarik yang ada di DTW. Potensi tersebut dapat berupa keindahan alam, kebudayaan daerah, situs bersejarah, pesta budaya dan keagamaan, pusat ekonomi dan perdagangan, serta tempat menarik yang tidak dimiliki daerah lain.

\section{METODE PENELITIAN}

Metode yang digunakan dalam penelitian ini adalah metode deskriptif yang dirancang untuk mengumpulkan informasi tentang keadaan-keadaan nyata sekarang (sementara berlangsung).

Tujuan utama dalam menggunakan metode ini adalah untuk membuat deskriptif, gambaran secara sistematis, faktual dan akurat mengenai fakta-fakta, sifatsifat serta hubungan fenomena yang diselidiki. Disamping itu, penelitian yang dilakukan tidak hanya mengumpulkan data saja, akan tetapi memberikan interpretasi atas data yang diperoleh.Dalam penelitian ini peneliti akan mengambil lokasi penelitian Dusun Sendang Kumitir Desa Kembang Arum , KecamatanTuri, Kabupaten Sleman.

Teknik pengumpulan data bersumber dari data primer yaitu informasi yang diperoleh dari sumbersumber primer yaitu yang asli, informasi dari tangan pertama atau responden (Wardiyanta, 2006). Penulis mendapat informasi langsung dari pihak pengelola Pesona Alam Dusun Sendang Kumitir Desa Kembang Arum , Turi, Sleman. Kemudian peneliti juga mengunakan data sekunder dimana informasi yang diperoleh tidak secara langsung dari responden, tetapi dari pihak ketiga (Wardiyanta, 2006).

Untuk mendapatkan hasil penelitian yang mendekati kebenaran maka digunakan instrumen sebagai berikut: 
a. Wawancara langsung. Metode wawancara adalah proses tanya jawab dalam penelitian yang berlangsung secara lisan. Penulis melakukan wawancara terhadap pihak yang terkait yaitu pihak pengelola Pesona Alam Dusun Sendang Kumitir Desa Kembang Arum , Turi, Sleman dan bagi wisatawan yang berkunjung di Pesona Alam Dusun Sendang Kumitir Desa Kembang Arum , Turi, Sleman

b. Kuesioner . Kuesioner merupakan alat pengumpulan data dengan membuat daftar pertanyaan yang diisi oleh wisatawan atau penggunjung yang berkunjung atau sudah berkunjung di Pesona Alam Dusun Sendang Kumitir Desa Kembang Arum, Turi, Sleman.

c. Pengamatan langsung (direct obsevation). Metode Observasi yaitu cara memperoleh data yang dilakukan dengan cara mengamati dan mencatat secara sistematisk gejala- gejala yang diselidiki. Dengan meninjau kegiatan-kegiatan dan kondisi yang ada di Pesona Alam Dusun Sendang Kumitir Desa Kembang Arum , Turi, Sleman tersebut. Penulis mendatangi langsung Pesona Alam Dusun Sendang Kumitir Desa Kembang Arum , Turi, Sleman tersebut supaya penulis dapat melihat dengan jelas bagaimana keadaannya.

d. Dokumentasi Dokumentasi ini dilakukan guna mendapatkan foto atau gambar kegiatan Pesona Alam Dusun Sendang Kumitir Desa Kembang Arum , Turi, Sleman.

e. Studi Pustaka Studi Pustaka dilakukan untuk mencari dan mendapatkan data-data yang bersifat teoritis dan berhubungan dengan penelitian yang sedang dilakukan. Denga mempelajari literatur-literatur, dan sumber-sumber lainnya dari internet yang berhubungan dengan penelitian. Pengumpulan data kepustakaan dilakukan terhadap data dan informasi dalam bentuk buku, laporan hasil penelitian dan sumber lainnya.

Analisis data yang digunakan dalam penelitian ini adalah analisis deskriptif, kualitatif yang pengujiannya bertitik tolak dari data yang telah terkumpul kemudian dilakukan penarikan kesimpulan. sedangkan penghitungan prosentase pendapat responden

\section{GAMBARAN UMUM PESONA ALAM DUSUN SENDANG KUMITIR}

1. Sejarah berdirinya Pesona Alam Dusun Sendang Kumitir

Pesona Alam Dusun Sendang Kumitir letaknya berada di Kecamatan Turi, tepatnya di Dusun Kembangarum XV Balong Kelurahan Donokerto kecamatan Turi Kabupaten Sleman Daerah Istimewa Jogjakarta. Dari arah kota Yogyakarta ke utara kurang lebih $15 \mathrm{Km}$ perjalanan.

Lokasinya yang sangat strategis diantara jalur wisata Borobudur, Kaliurang dan Prambanan menjadikan tempat ini ramai dilewati kendaraaan sehingga tempat ini cocok dibangun untuk mendatangkan wisatawan atau pengunjung. Perintis tempat wisata ini adalah Bapak Ahmadi Prasetyo, S.Pd, dan diresmikan tahun 2010 yang lalu. Ditangan beliaulah dusun balong yang penuh kebun salak dijadikan tempat wisata kulineri dan tempat wisata pendidikan. Halaman samping rumahnya yang penuh kebun salak dijadikan kolam pemancingan sekaligus resto kemudian dilengkapi sarana outbound yang penuh keindahaan alam disana-sini. Pelan dan pasti daerahnya yang tadinya hanya penuh kebun salak serta potensi air yang melimpah maka dusun balong disulap menjadi daerah wisata kulineri dan wisata pendidikan alam.

Pesona Alam Dusun Sendang Kumitir adalah resto yang menghadirkan kesan suasana desa yang ditampilkan melalui gubuk-gubuk yang dibangun disamping kolam memancing. suasana sejuk yang jauh dari polusi udara membuat tempat ini adem ayem, asri dan membuat orang yang datang di sini menjadi kerasan mampir. Belum lagi fasilitas memancing ikan memberikan hiburan tersendiri bagi pengunjung. Olahan khas Sendang kumitir adalah ikan bakar atau goreng. Kelebihan olahan ikan di Sendang Kumitir ini adalah ikan yang di masak adalah ikan fresh langsung di ambil dari kolam, Selain menyediakan olahan khas ikan bakar/goreng, Sendang Kumitir mengusung konsep rumah makan "Ndeso" ini juga menyediakan tempat outbond untuk instansi, sekolah, organisasi dan lain-lain.

Dengan konsep wisata kulineri dan wisata pendidikan maka Pesona Alam Dusun Sendang menjadi tujuan pengunjung atau wisatawan yang ingin menikmati kulineri atau mengadakan pelatihan pengembangan diri seperti outbound. Setiap bulan tempat ini selalu penuh pengunjung atau instansi yang ingin menikamti hasil kulineri dan mengadakan outbound. Sebagai pemilik usaha ini, Bapak Ahmadi Prasetyo, S.Pd selalu melibatkan warga dusun Balong untuk mengembangkan diri untuk bersama-sama memajukan dusunnya. Dengan demikian pertumbuhaan ekonomi dusun menjadi meningkat.

Sebagai tempat wisata kulineri dan wisata pendidikan alam yang dapat diakses dengan mudah karena berada dijalur wisata Borobudur - Kaliurang Prambanan serta disekelilinginya juga banyak desa wisata maka wajar pengunjung atau wisatawan banyak berkunjung ke Pesona Alam Dusun Kumitir.

\section{Fasilitas Pendukung Pesona Alam Dusun Kumitir}

Sebagai daerah yang mempunyai potensi pariwisata dengan prospek yang tinggi untuk dikunjungi, maka Pesona Alam Dusun Kumitir tentu didukung sarana prasarana yang memadai meski tidak mewah. Hal karena ini dikarenakan lebih ditonjolkan alami atau desanya maka sarana prasarana lebih sederhana. Namun semua sarana-prasaran mudah diakses dan dinikmati.

Adapun sarana-prasarana yang ada di Pesona Alam Dusun Kumitir antara lain :

\section{Akses Jalan Menuju Pesona Alam Dusun Kumitir}

Sebagai tempat wisata pendidikan dan kulineri Pesona Alam Dusun Kumitir tentu sarana jalan sangat menentukan ramai tidaknya usaha tersebut. Untuk akses 


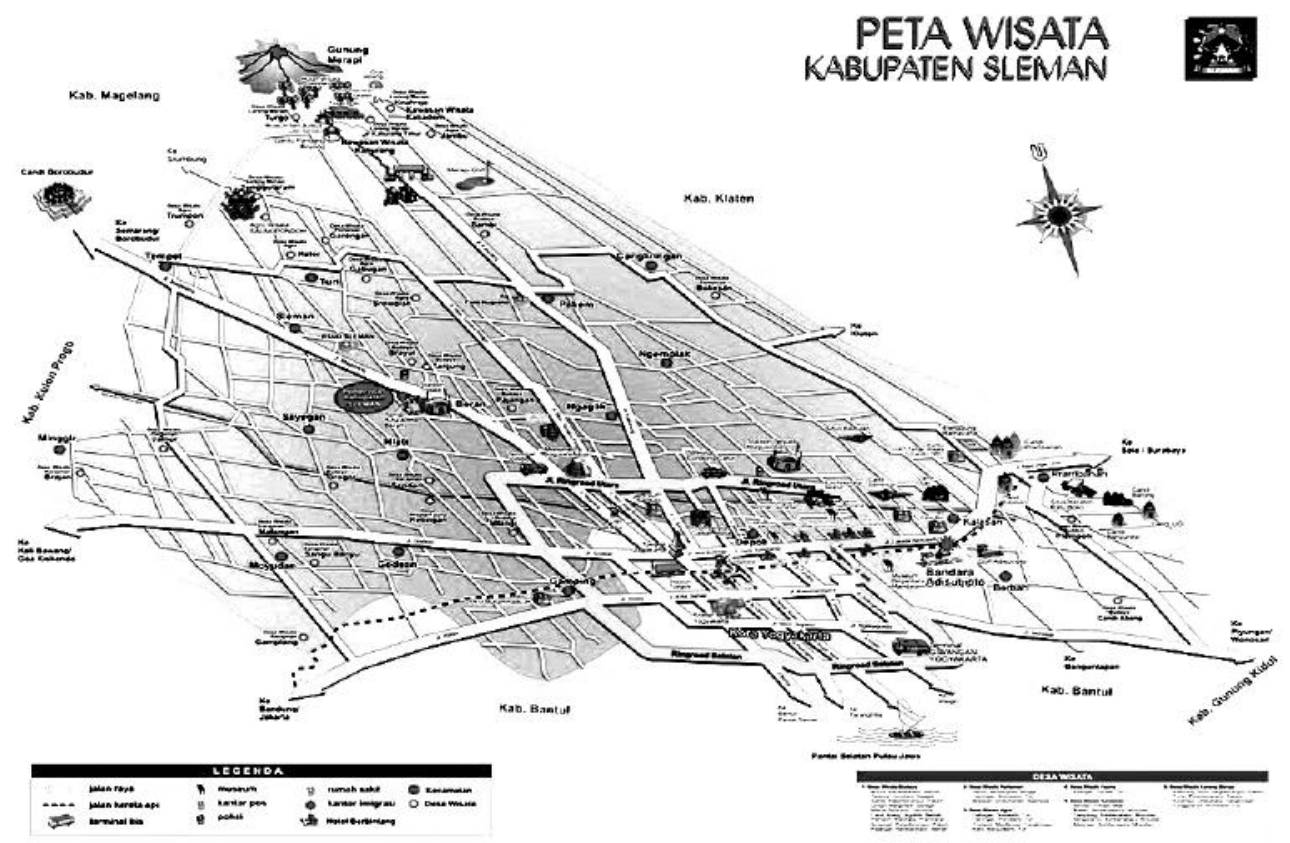

Gambar 1

Peta Akses Menuju Pesona Alam DusunKumitir, Kembang Arum, Turi, Sleman Sumber : Dinas Pariwisakta Sleman, Yogyakarta

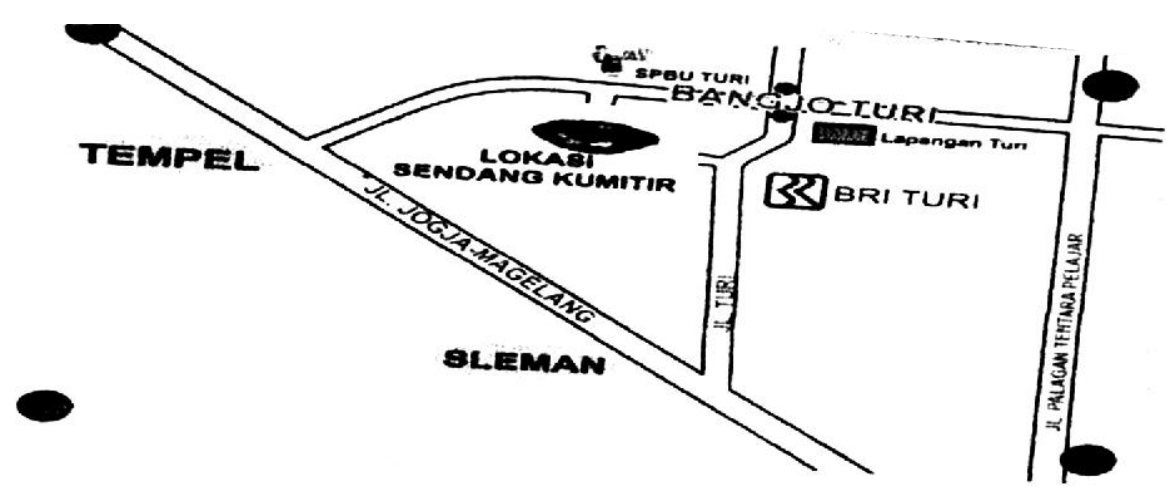

Gambar 2

Petunjuk Menuju Pesona Alam Dusun Kumitir, Kembang Arum, Turi, Sleman Sumber : Dokumen Pengelola Pesona Alam DusunKumitir, 2015

jalan menuju Pesona Alam Dusun Kumitir sudah baik meski ditengah desa dan jalan menuju lokasi tersebut mudah dikenal karena petunjuk arah yang dibuat sebelum masuk ke desa tersebut.

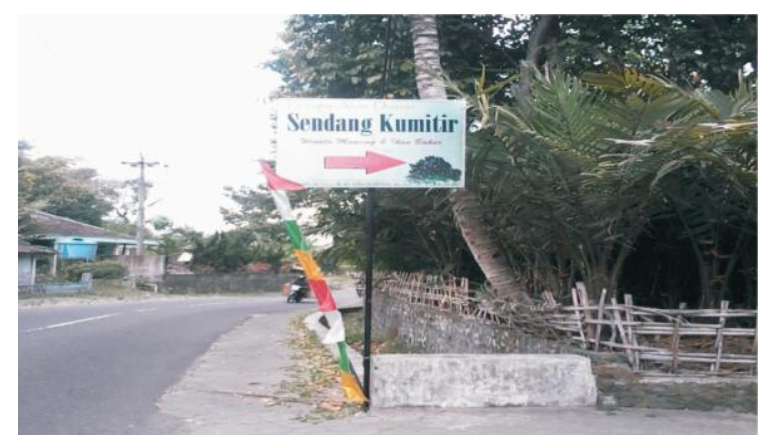

Gambar 3.

Penunjuk Jalan Menuju Pesona Sendang Kumitir
2. Parkir Kendaraan di Pesona Alam Sendang Kumitir. Sebagai wisata kulineri dan pendidikan untuk memberi rasa nyaman bagi pengunjung untu itu pengelola Pesona Alam Sendang Kumitir menyediakan sarana prakir kendaraan baik roda dua maupun empat.

3. Fasilitas Mushola dan Kamar Mandi. Untuk mendukung kenyaman pengunjung di tempat wisata Pesona Alam Sendang Kumitir maka fasilitas tempat ibadah yaitu Musholla juga tersedia yang bisa digunakan untuk ibadah sholat bagi pengunjung. Kemudian toilet atau kamar mandi juga disediakan lebih dari 2 kamar mandi. Karena saat kegiatan outbound kamar mandi juga digunakan untuk mandi para peserta outbound karena mereka biasanya basah saat outbound dikolam maupun disungai. 
4. Fasilitas Permainan Outbound di Pesona Alam Sendang Kumitir Pesona Alam Sendang Kumitir saat dibangun sudah mempunyai kelebihan dengan keindahaan alam sehingga sering digunakan untuk wisata pendidikan salah satunya adalah kegiatan Outbound. Dengan dukungan lingkungan yang asri dan nyaman menjadikan pengunjung sangat terkesan. Lahan yang luas memberikan kesan lapang bagi peserta outbound ketika mereka memainkan segala perintah instruktur trainer. Kemudian sungai dan sawah yang mendukung kegiatan outbound tentunya memberikan keasikan bagi pengunjung Pesona Alam Sendang Kumitir.

Adapun fasilitas untuk mendukung kegiatan Outbound sebagai berikut :

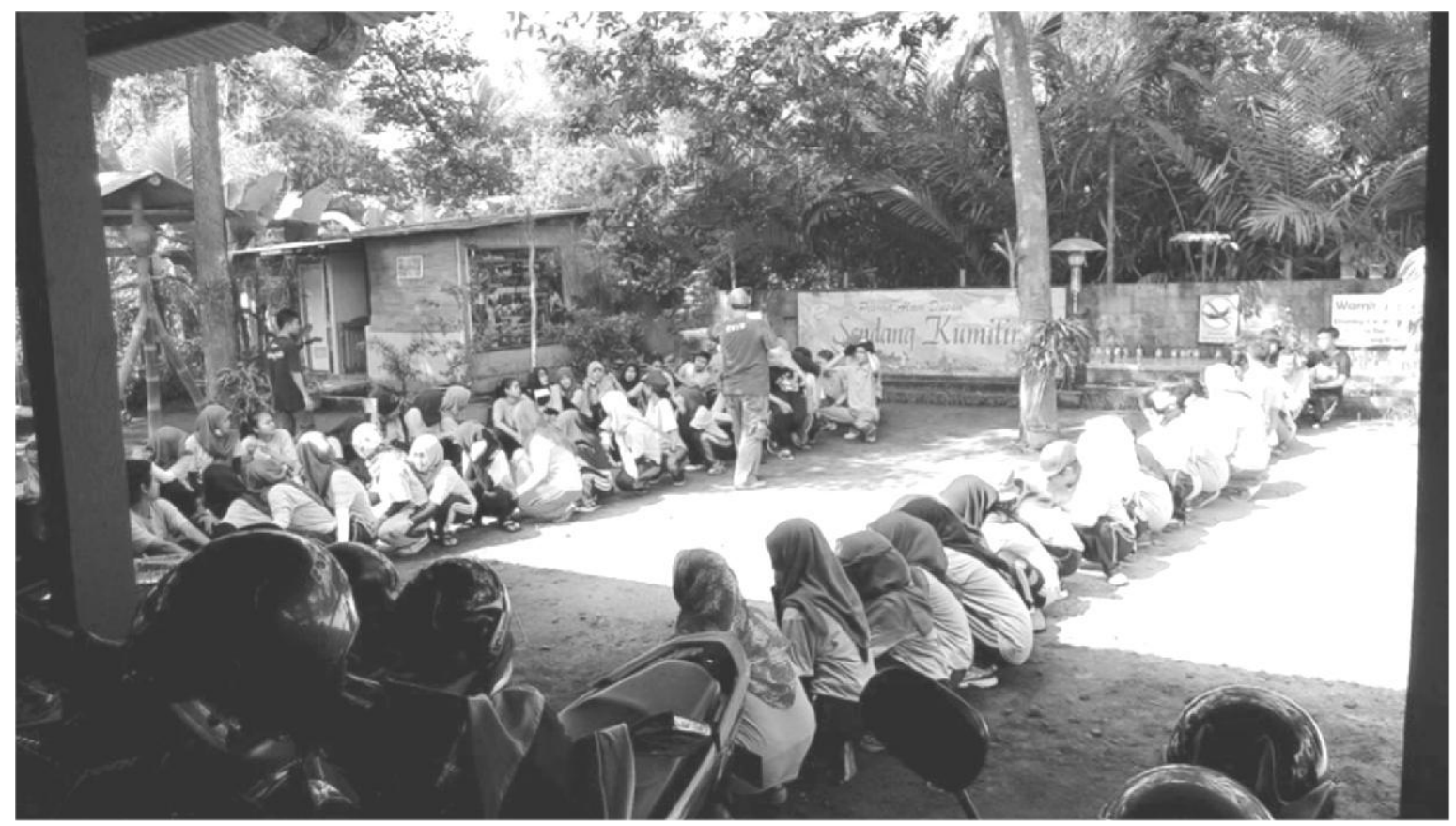

Gambar 4. Kegiatan Outbound di Halaman Pesona Alam Sendang Kumitir

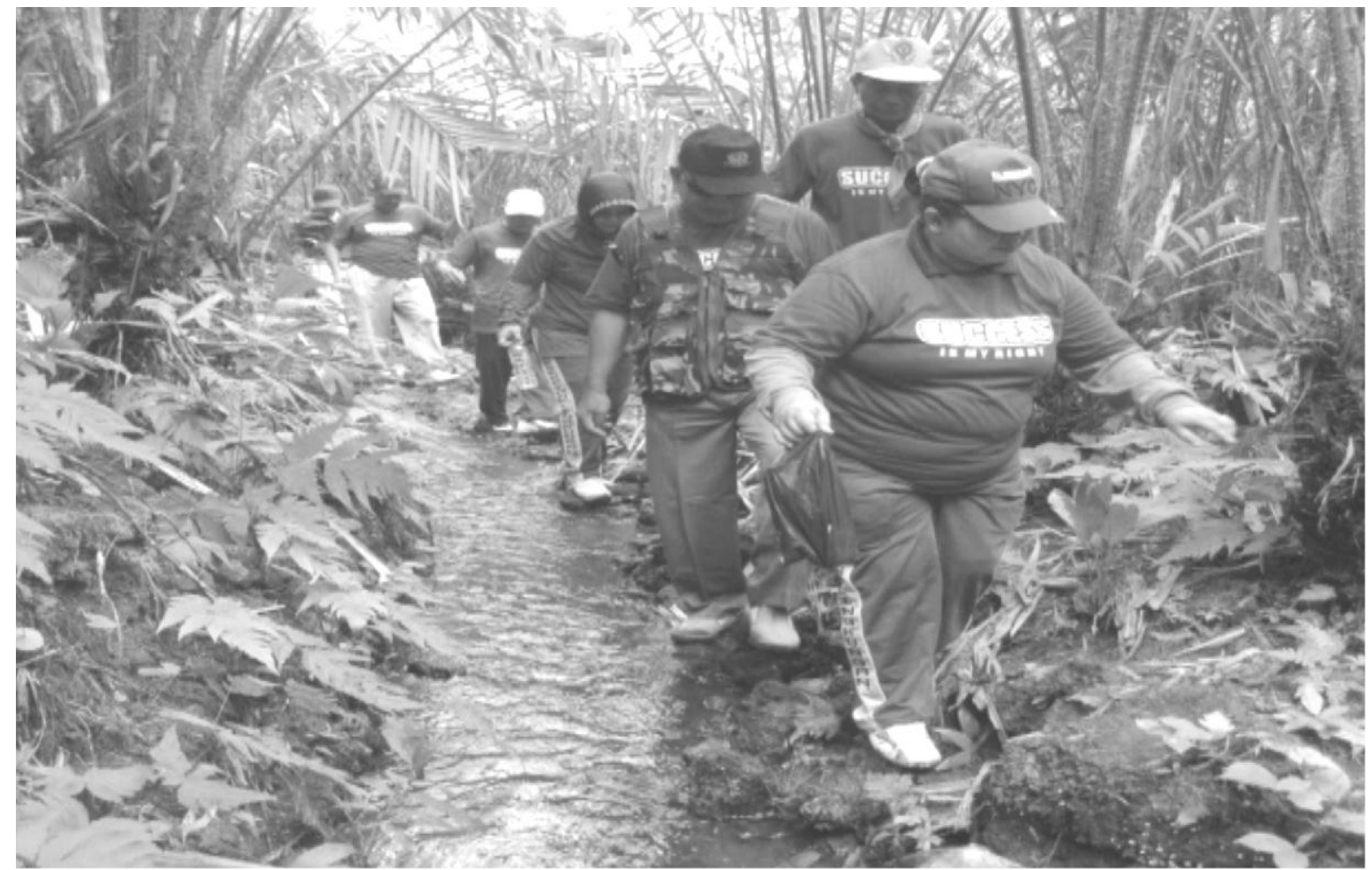

Gambar 5 Kegiatan Outbound di Sungai dan Kebun Salak Pesona Alam Sendang Kumitir. Sumber : dokumen pesona alam sendang kumitir, 2015 
5. Fasilitas Kulineri Pesona Alam Sendang Kumitir

Sebagai ikon tempat wisata pendidikan dan kulineri maka Pesona Alam Sendang Kumitir selalu menawarkan pesona alam dan makanan khasnya. Adapun makannan khasnya adalah olahaan ikan tawar yang hidup dikolam dan sungai-sungai di sekitar lokasi wisata tersebut. Kolam-kolam yang menyatu dengan kebun salak menambah keasrian lokasi wisata tersebut. Dengan mengambil ikan sendiri atau memancing para wisatawan bisa menikmati ikan untuk diolah oleh pemilik atau bisa diambilkan oleh pemilik.

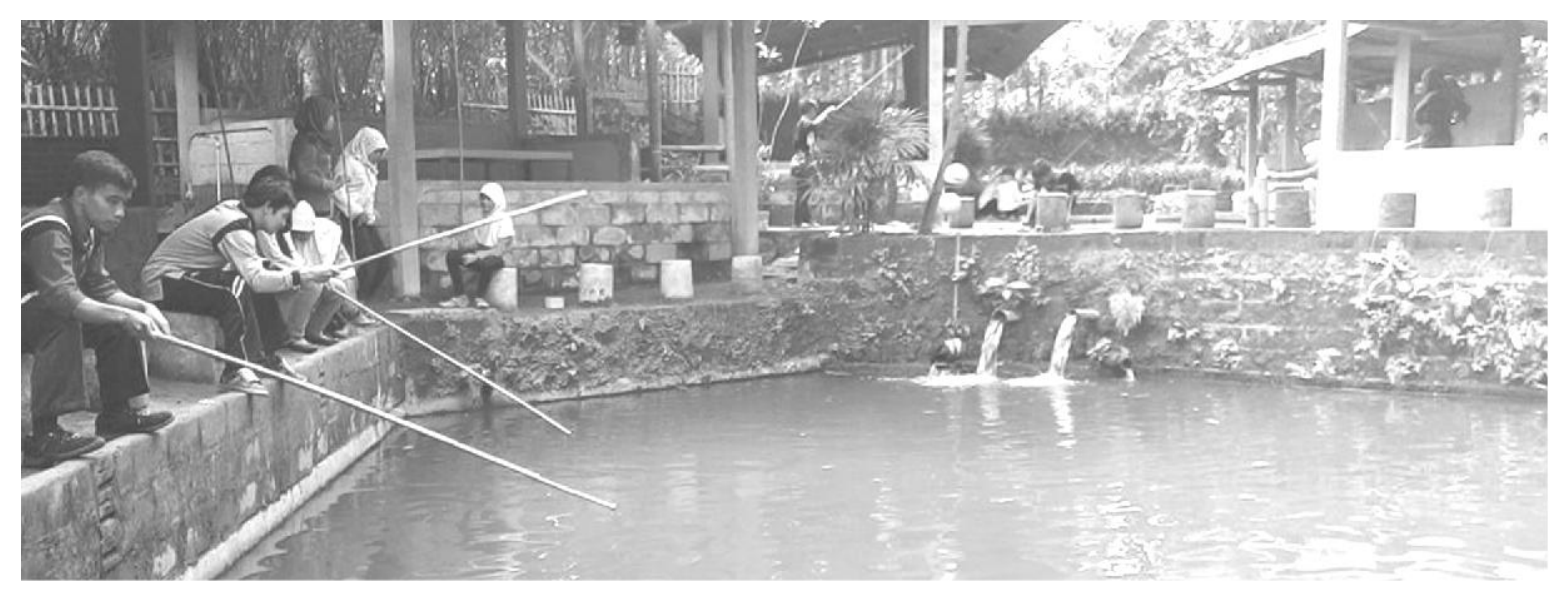

Gambar 6. Kolam Pemancingan Pesona Alam Sendang Kumitir

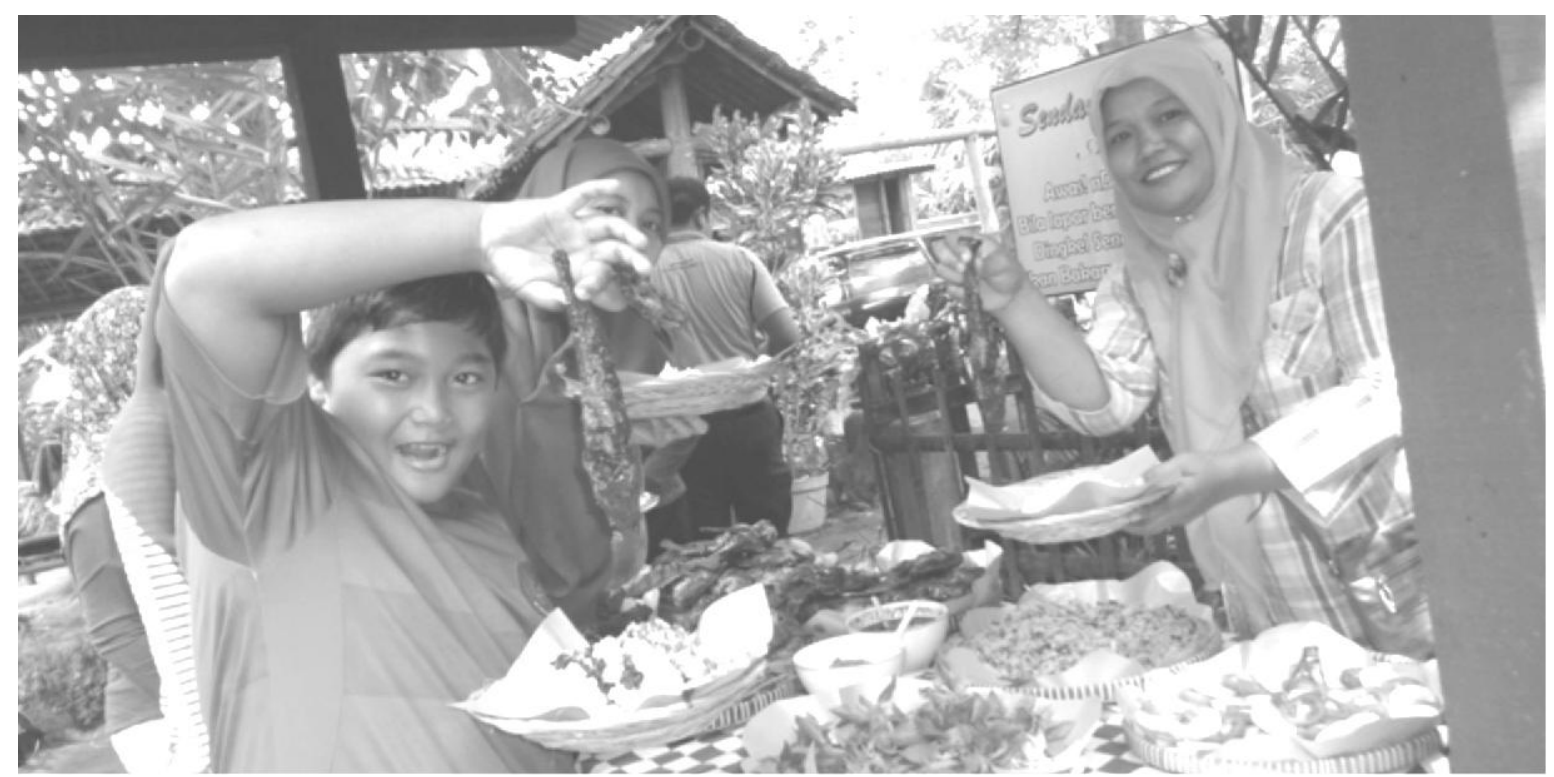

Gambar 7. Aktivitas Kulineri di Pesona Alam Sendang kumitir

Sumber : dokumen pesona alam sendang kumitir, 2015

\section{PEMBAHASAN}

1 Analisis Strength, Weakness, Opportunity dan Threats (SWOT) Pesona Alam Sendang Kumitir

Sebagai wisata pendidikan dan kulineri Pesona Alam Sendang Kumitir mempunyai potensi yang luar biasa yang dapat dikembangkan lebih besar lagi. Sebagai daerah yang mempunyai potensi mendatangkan pengunjung atau wisatawan tentunya ada faktor-faktor yang menyebabkan Pesona Alam Sendang Kumitir akan dikunjungi wisatawan. Adapun faktor-faktor tersebut berupa keindaahaan alam, kebersihannya. akses atau kemudahaan dikunjungi, sarana-prasarananya dan promisi. Potensi-potensi inilah yang kemudian saya analisis dengan analisis SWOT yang meliputi Kekuatan, Kelemahan, Peluang Serta Ancaman yang di Pesona Alam Sendang Kumitir. Melalui analisis SWOT ini dapat menjadi pertimbangan dalam menentukan pengembangan Pesona Alam Sendang Kumitir. Dengan analisis inilah pengelola dapat melakukan strategi pemasaran Pesona Alam Sendang Kumitir agar tempat ini menjadi besar dan lebih sukses dalam meraih pelanggan untuk berkunjung ke lokasi tersebut.

Analisis SWOT Pesona Alam Sendang Kumitir dapat dijelaskan sebagai berikut ini. 
Tabel 1. Analisis SWOT Pesona Alam Sendang Kumitir

\begin{tabular}{|c|c|c|}
\hline No & Faktor Penentu & Keterangan \\
\hline & Kekuatan (strength) & $\begin{array}{l}\text { Pesona Alam Sendang Kumitir sangat strategis karena berada dijalur pariwisata } \\
\text { Prambanan-Kaliurang-Borobudur. } \\
\text { Pesona Alam Sendang Kumitir dapat diakses dengan kendaraan roda } 2 \text { dan } 4 \\
\text { dari berbagai arah } \\
\text { - Pesona Alam Sendang Kumitir mempunyai potensi alam yang indah dan } \\
\text { berhawa sejuk karena dekat dengan Gunung Merapi } \\
\text { - Pesona Alam Sendang Kumitir mempunyai sumber air alami dan kebun salak } \\
\text { yang luas. } \\
\text { Pesona Alam Sendang Kumitir terletak lokasi yang tidak jauh dari kampus UGM, } \\
\text { UNY,UIN sehingga mempunyai masyarakat dengan tingkat mobilitas yang } \\
\text { tinggi. } \\
\text { Masyarakat Yogyakarta khususnya di Sleman terhadap wisata kulineri sangat } \\
\text { tinggi sehingga rasa ingin tahu sangat tinggi terhadap makanan khas. } \\
\text { Ketersediaan lahan yang luas sehingga memudahkan aktivitas outbound menjadi } \\
\text { terakomodasi }\end{array}$ \\
\hline & $\begin{array}{l}\text { Kelemahan } \\
\text { (weakness) }\end{array}$ & $\begin{array}{l}\text { Akses (jalan) menuju Pesona Alam Sendang Kumitir masih sempit, sehingga } \\
\text { kendaraan roda } 4 \text { harus bergantian dan jenis kendaraan bus harus diparkir diluar } \\
\text { desa. } \\
\text { - Kurangnya SDMyang membantu apabila pengunjung ramai sehingga pelayanan } \\
\text { agak lama pada saat menikamti kulineri di Pesona Alam Sendang Kumitir } \\
\text { - Kurang lengkapnya fasilitas permainan anak-anak. } \\
\text { - Kurangnya informasi dan promosi tentang Pesona Alam Sendang Kumitir di } \\
\text { media cetak atau brosur hanya media sosial saja atau dari mulut ke mulut saja. }\end{array}$ \\
\hline & $\begin{array}{l}\text { Peluang } \\
\text { (opportunities) }\end{array}$ & $\begin{array}{l}\text { Dapat membuka lapangan pekerjaan bagi warga disekitar Pesona Alam Sendang } \\
\text { Kumitir. } \\
\text { - Menambah fasilitas permainan anak-anak Pesona Alam Sendang Kumitir. } \\
\text { - Saat ini wisata kulineri sedang trend perkembangannya sehingga } \\
\text { pengembangan wisata kulineri di Pesona Alam Sendang Kumitir dapat lebih } \\
\text { ditingkatkan menjadi lebih besar. } \\
\text { Banyak media massa maupun cetak dan elektronik yang mengekspose tentang } \\
\text { masalah wisata kulineri sehingga berpengaruh positif terhadap wisata } \\
\text { pendidikan dan kulineri Pesona Alam Sendang Kumitir } \\
\text { Adanya perubahaan minat para wisatawan khususnya wisatawan nusantara dari } \\
\text { wisata konvensional ke jenis wisata alternatifyaitu wisata pendidikan dan kulineri } \\
\text { dan semua ada Pesona Alam Sendang Kumitir } \\
\text { Kehidupan masyarakat Pesona Alam Sendang Kumitir yang masih asli } \\
\text { merupakan peluang untukmenarik wisatawan khususnya mancanegara }\end{array}$ \\
\hline & Ancaman (threats) & $\begin{array}{l}\text { - Banyak daerah disekitar Pesona Alam Sendang Kumitir yang membuka usaha } \\
\text { yang sama sehingga menjadi kompetitor atau pesaing. }\end{array}$ \\
\hline
\end{tabular}

Sesuai dengan analisis SWOT diatas maka permasalahan di Pesona Alam Sendang Kumitir dapat diidentifikasikan sehingga kekuatan atau faktor yang baik serta peluang yang dimiliki dapat dikembangkan lebih meningkat kedepan. Namun kita tidak bisa menutup mata adanya faktor kelemahaan dan ancaman yang dapat menghambat pengembangan Pesona Alam Sendang Kumitir itu sendiri kedepan. Dari uraian di atas maka dapat disimpulkan bahwa Pesona Alam Sendang Kumitir dapat dikembangkan lebih meningkat atau menjadi besar sebagai tujuan wisata pendidikan dan kulineri
Analisis Responden Tentang Pesona Alam Sendang Kumitir

Dalam penelitian ini peneliti juga melakukan penyebaran kuesioner yang bertujuan untuk mengetahui seberapa jauh pendapat tentang layanan dan gambaran para responden yang telah berkunjung atau saat berkunjung di Pesona Alam Sendang Kumitir. Adapun kuesioner yang kita bagikan kepada responden atau pengunjung memuat tentang profile responden meliputi umur, jenis kelamin, pendapatan dan daerah asal pengunjung. Kemudia pernyataan tentang akses jalan menuju Pesona Alam Sendang Kumitir, 
Pengetahuan terhadap Pesona Alam Sendang kumitir,Daya Tarik serta kelengkapan yang dimilikinya. Kemudian yang paling penting adalah pelayanan pengelola Pesona Alam Sendang Kumitir. Serta respon pengunjung untuk berkunjung lagi dan mencerikan ke orang lain tentang Pesona Alam Sendang Kumitir.

Adapun datanya serta analisisnya dapat dijelaskan sebagai berikut :

Tabel 3. Data Asal Responden Berkunjung

\begin{tabular}{|c|c|c|c|}
\hline No & Daerah & Frekuensi & Persentase \\
\hline 1 & Sleman & 29 & $63 \%$ \\
\hline 2 & Kota Yogyakarta & 4 & $9 \%$ \\
\hline 3 & Bantul & 0 & $0 \%$ \\
\hline 4 & Kulon Progo & 3 & $6 \%$ \\
\hline 5 & Gunungkidul & 2 & $4 \%$ \\
\hline 6 & Luar Yogyakarta & 8 & $17 \%$ \\
\hline & Total & 46 & $100 \%$ \\
\hline
\end{tabular}

Dari tabel 4.3 maka dapat hasil hitungan bahwa terdapat 63\% berasal dari kabupaten Sleman dimana obyek wisata tersebut berada, kemudian $9 \%$ berasal dari kota Yogyakarta, 17\% berasal dari kabupaten Kulon Progo, dan 4\% kabupaten Gunungkidul dan hanya sekian $17 \%$ berasal dari wilayah diluar Yogyakarta.Dengan demikian bahwa pengunjung atau wisatawan yang paling banyak dari kabupaten Sleman karena obyek ada didaerah tersebut.

Minat dan Dengan Siapa Responden Berkunjung Pesona Dusun Sendang Kumitir
Pada table ini, dimaksudkan untuk melihat atau berkeinginan dari responden dan dengan siapa responden mengunjungi obyek wisata Pesona Alam Dusun Sendang Kumitir tersebut, apakah minat tersebut karena faktor niat dari sendiri, karena diajak oleh teman, ataupun hanya karena faktor menemani keluarga saja untuk berwisata, serta dengan siapa responden dalam berkunjung ke obyek wisata tersebut. Maka keterangan tersebut dapat dilihat pada tabel dibawah ini.

Tabel 4. Data Keinginan Berkunjung

\begin{tabular}{|l|l|c|c|}
\hline No. & Keterangan & Frekuensi & Persentase \\
\hline 1. & Dari diri sendiri & 9 & $20 \%$ \\
\hline 2. & Diajak orang lain & 33 & $72 \%$ \\
\hline 3. & Mengantar keluarga & 4 & $8 \%$ \\
\hline \multicolumn{2}{|r|}{ Total } & 46 & $100 \%$ \\
\hline
\end{tabular}

Dari tabel di atas, bahwa gambaran bahwa sebagian responden berkunjung ke Pesona Alam Dusun Sendang Kumitir karena diajak orang lain sebanyak 33\% responden dan yang datang karena diri sendiri atau inisiatif sendirinya 20\% responden kemudian sisanya karena mengantar keluarga ada $8 \%$.

Tabel 5. Data Dengan Siapa Responden Berkunjung

\begin{tabular}{|l|l|c|c|}
\hline No. & Keterangan & Frekuensi & Persentase \\
\hline 1. & Sendiri & 1 & $2 \%$ \\
\hline 2. & Teman dekat & 3 & $6 \%$ \\
\hline 3. & Keluarga & 25 & $54 \%$ \\
\hline 4 & Rombongan & 17 & $36 \%$ \\
\hline \multicolumn{2}{|r|}{ Total } & 46 & $100 \%$ \\
\hline
\end{tabular}

Pengunjung datang ke Pesona Alam Dusun Sendang Kumitir menurut data yang ada di tabel 4.5 bahwa sebanyak $54 \%$ responden berkunjung ke obyek wisata dengan keluarga, 36\% datang dengan rombongan, $6 \%$ dengan teman dekat dan sisanya $2 \%$ datang sendiri.

Akses Dalam Menuju Pesona Alam Dusun Sendang Kumitir
Bahwa sebuah obyek wisata dapat berkembang dan selalu dikunjungi wisatawan apabila aksesnya mudah dijangkau dan mudah dicari. Untuk itu data ditabel dibawah ini untuk mengetahui menggunakan sarana apa responden berkunjung, kemudahaan responden jika menggunakan sarana umum serta kondisi jalan menuju ke Pesona Alam Dusun Sendang Kumitir. 
Tabel 6. Data Sarana Kendaraan Responden Saat Berkunjung

\begin{tabular}{|c|c|c|c|}
\hline No. & Keterangan & Frekuensi & Persentase \\
\hline 1. & Pribadi & 40 & $87 \%$ \\
\hline 2. & Umum & 6 & $13 \%$ \\
\hline & Total & 46 & $100 \%$ \\
\hline
\end{tabular}

Sesuai tabel diatas maka responden yang menggunakan kendaraan pribadi paling dominan yang sebesar $87 \%$ dan hanya $6 \%$ saja yang menggunakan sarana kendaraan umum yaitu menggunakan bus atau mobil carteraan.

Daya Tarik Dan Kelengkapan Yang Ada Di Pesona Dusun Sendang Kumitir
Dalam sebuah obyek wisata biasanya pengelola memberikan kelengkapan atau fasilitas yang memberikan faktor penarik wisatawan atau pengunjung. Untuk itu tabel dibawah ini memberikan informasi apa saja yang menjadikan daya tarik pengunjung ke Pesona Alam Dusun Sendang Kumitir.

Tabel 7. Data Daya Tarik Yang Ada di Pesona Dusun Sendang Kumitir

\begin{tabular}{|c|c|c|c|}
\hline No. & Keterangan & Frekuensi & Persentase \\
\hline 1. & Keindahaan alam & 10 & $22 \%$ \\
\hline 2. & Arena permainan & 4 & $8 \%$ \\
\hline 3. & Acara dan hiburan & 2 & $4 \%$ \\
\hline 4 & Lokasi yang nyaman & 22 & $49 \%$ \\
\hline 5 & Resto atau kulinerinya & 8 & $17 \%$ \\
\hline & Total & 46 & $100 \%$ \\
\hline
\end{tabular}

Sesuai tabel diatas bahwa pengunjung atau wisatawan berkunjung ke Pesona Alam Dusun Sendang Kumitir karena lokasi yang nyaman itu menurut $49 \%$ responden hal ini dikarenakan tempatnya yang dikelilingi banyak kebun salak, Untuk faktor Keindahaan alam ada $22 \%$ responden yang memilih, $17 \%$ karena resto atau kulinerinnya sisanya $8 \%$ dan $4 \%$ karena arena permainan dan acara serta hiburannya.

Tabel 8. Data Kelengkapan Dalam Fasilitas Yang Dimiliki

Di Pesona Dusun Sendang Kumitir

\begin{tabular}{|l|l|c|c|}
\hline No. & Keterangan & Frekuensi & Persentase \\
\hline 1. & Lengkap & 20 & $43 \%$ \\
\hline 2. & Tidak Lengkap & 26 & $57 \%$ \\
\hline \multicolumn{2}{|l|}{ Total } & 46 & $100 \%$ \\
\hline
\end{tabular}

Sebagai obyek wisata pendidikan dan kulineri Keindahaan alam Pesona Alam Dusun Sendang Kumitir belum mempunyai fasilitas pendukung yang diinginkan wisatawan hal ini ditunjukkan belum lengkapnya fasilitas penunjang menurut $57 \%$ responden seperti toilet atau kamar mandi, arena bermain anak atau wifi dan $43 \%$ yang mengatakan sudah lengkap.
Kondisi Kebersihan di Pesona Dusun Sendang Kumitir Pesona Alam Dusun Sendang Kumitir sebagai obyek wisata pendidikan dan kulineri selalu menjaga faktor kebersihan, untuk itu faktor ini sangat menentukan wisatawan akan menilai bersih atau tidak obyek tersebut sehingga akan berkunjung dengan puas.

Tabel 9. Data Tentang Kondisi Kebersihan di Pesona Dusun Sendang Kumitir

\begin{tabular}{|c|c|c|c|}
\hline No. & Keterangan & Frekuensi & Persentase \\
\hline 1. & Bersih & 31 & $67 \%$ \\
\hline 2. & Kotor & 15 & $33 \%$ \\
\hline & Total & 46 & $100 \%$ \\
\hline
\end{tabular}


Dari data tabel diatas bahwa $67 \%$ responden mengatakan fasilitas pendukung di Pesona Alam Dusun Sendang Kumitir dalam kondisi bersih dan hanya 33\% mengatakan kotor.

b. Harga Yang Dikenakan Di Pesona Dusun Sendang Kumitir
Faktor harga sangat menentukan orang akan berkunjung ke obyek wisata, sebagai wisata pendidikan dan kulineri maka Pesona Alam Dusun Sendang Kumitir tentu dalam menetapkan harga sangat ditentukan kondisi saat ini. Untuk itu tabel dibawah ini menunjukkan harga ketika orang berkunjung ke Pesona Alam Dusun Sendang Kumitir.

Tabel 10. Data Tentang Harga Di Pesona Dusun Sendang Kumitir

\begin{tabular}{|l|l|c|c|}
\hline No. & Keterangan & Frekuensi & Persentase \\
\hline 1. & Mahal & 15 & $33 \%$ \\
\hline 2. & Murah & 31 & $67 \%$ \\
\hline \multicolumn{2}{r|}{ Total } & 46 & $100 \%$ \\
\hline
\end{tabular}

Untuk harga yang ditetapkan di obyek wisata Pesona Alam Dusun Sendang Kumitir menurut 67\% responden sangat murah meliputi harga makanan atau kulinerinya sisanya yang mengatakan mahal $33 \%$ responden.

Pelayanan Di Pesona Dusun Sendang Kumitir
Dalam pengelolaan obyek wisata di Pesona Alam Dusun Sendang Kumitir faktor pelayanan sangat diutamakan sebagai hal yang harus dilakukan oleh pemilik dan karyawan ditempat tersebut. Data tabel dibawah ini akan memberikan informasi tentang masalah pelayanan di Pesona Alam Dusun Sendang Kumitir.

Tabel 11. Data Pelayanan Selama Responden Berkunjung di Pesona Dusun Sendang Kumitir

\begin{tabular}{|l|l|c|c|}
\hline No. & Keterangan & Frekuensi & Persentase \\
\hline 1. & Menyenangkan & 37 & $80 \%$ \\
\hline 2. & Tidak menyenangkan & 9 & $20 \%$ \\
\hline \multicolumn{2}{r}{ Total } & 46 & $100 \%$ \\
\hline
\end{tabular}

Dari data diatas bahwa $80 \%$ responden mengatakan bahwa pelayanan di Pesona Alam Dusun Sendang Kumitir sangat menyenangkan seperti pelayanan yang ramah, cepat dan tanggap, Hanya 20\% yang mengatakan tidak menyenangkan, mungkin ini disebabkan karena saat ramai ada pengunjung yang tidak terlayani dengan ramai.

Hasil intreview dengan pengelola Pesona Alam Sendang Kumitir untuk menarik pengunjung atau wisatawan dalam hal ini dengan melalui :

1. Suasana alam ndesonya yang dijual kepada wisatawannya

2. Akses jalan dan penunjuk arah jalan ke obyek wisata yang jelas

3. Citra masakkannya dari wisata kulinerinya yang khasnya yaitu ikan bakarnya yang menjadi favorit.

4. Wisata pendidikan yaitu outbound yang dikemas dengan suasana alam desa.

5. Kegiatan mancing bersama dengan keluarga dan instansi yang membuat kesan dikemudian hari untuk berkunjung kembali serta mengajaik rekan, saudara dan keluarga sehingga promosi dari mulut ke mulut lebih efektif.

Dalam pengelolaan Pesona Alam Dusun Sendang Kumitir menurut pemilik masih mempunyai kendala- kendala meski dalam prakteknya obyek wisata tetap ramai dikunjungi. Kata pengelolanya kendala-kendala yang masih dipikirkan adalah :

\section{Permodalan}

Untuk mengembangkan Pesona Alam Dusun Sendang Kumitir lebih besar dengan fasilitas yang lengkap maka perlu modal yang besar. Inilah yang menjadi kendala pemilik untuk memperoleh modal yang besar.

\section{Tenaga Kerja}

Masalah tenaga kerja yaitu mimimnya pegawai bagian pelayanan di aspek wisata kulinerinya di dalam pengelolaan Pesona Alam Dusun Sendang Kumitir. Saat pengunjung ramai pelayanan tentunya harus cepat dan tepat sehingga perlu pegawai yang banyak. Disnilah kendala pegawai yang masih kurang sehingga waktu pelayanan menjadi agak lama. Kemudian saat permintaan wisata pendidikan yaitu outbound juga mencari orang untuk membantu kegiatan tersebut juga mengalami kendala dengan peserta outbound yang banyak.

\section{Promosi}

Pengelola Pesona Alam Dusun Sendang Kumitir mengalami kendal juga dalam promosi meski sudah mulai terkenal namun untuk promosi secara maksimal. Meski pemasaran masih melalui mulut ke mulut namun masih dirasa masih kurang. 


\section{Akses Jalan}

Menurut Pengelola Pesona Alam Dusun Sendang Kumitir bahwa akses jalan masuk lokasi wisata pendidikan dan wisata kulineri ini masih sempi karena ada didalam atau ditengah desa. Sehingga akses kendaraan besar seperti bus tidak bisa harus diparkir dipinggir jalan besar yang jaraknya 200 Meter dari lokasi. Kemudian jalan yang agak sempit karena jalan kampung sehingga ketika ada mobil bertemu harus mengalah.

5. Pengetahuan Pengelola

Pengelola menyadari dalam memanajemen tempat wisata pendidikan dan kulineri perlu ketrampilan dan pengetahuan yang khsusu sehingga dalam aktivitas sehari-hari pengelola masih menggunakan cara pengelolaan serabutan. Artinya belum ditangani secara profesional.

Dari kendala-kendala diatas pengelola Pesona Alam Dusun Sendang Kumitir berupaya mengatasi dengan tetap kerja semangat untuk melayani pengunjung wisata pendidikan dan wisata kulineri, promosi dengan mulut dengan mulut yang lebih efektif karena hasilnya juga nyata karena pengunjung dari waktu ke waktu juga bertambah.

Meski promosi dari mulut ke mulut efektif namun pengelola juga melakukan promosi melalui media sosial meski masih sederhana karena keterbatasan pengelola dalam mengelolanya akses tersebut. Adapun media sosial yang digunakan adalah Facebook dan Blogspot namun ini sebagai cara mengenalkan tempat wisata pendidikan dan kulineri. Terbukti banyak yang mengakses media sosial tersebut.

\section{KESIMPULAN}

Berdasarkan pembahasan tentang Strategi Pemasaran Pesona Alam Dusun Sendang Kumitir dapat disimpulkan sebagai berikut :

1. Sarana-prasarana di Pesona Alam Dusun Sendang Kumitir cukup mendukung untuk pengunjung yang menikmati wisata pendidikan dan wisata kulineri.

2. Hasil analisis SWOT bahwa di Pesona Alam Dusun Sendang Kumitir ternyata aspek keunggulannya dari aspek lokasi yang mendukung yaitu masih asri dan alami, Kelemahaanya masih dikelola dengan sederhana, Peluangnya masih bisa dikembangkan lebih besar lagi dan ancamanya adalah pesaing dengan usaha yang sama disekitar Pesona Alam Dusun Sendang Kumitir.

3. Hasil data pengunjung atau responden tentang Pesona Alam Dusun Sendang Kumitir bahwa pengunjung banyak didominasi wilayah kabupaten Sleman dimana lokasi ada diwilayah tersebut, kemudian pengunjung yang berkunjung kebanyakan didominasi keluarga, Pengunjung memperoleh informasi dari saudara dan teman tentang Pesona Alam Dusun Sendang Kumitir.

4. Menurut pengunjung bahwa pelayanan di Pesona Alam Dusun Sendang Kumitir sangat menyenangkan, kemudian keinginan berkunjung kembali ke obyek tersebut menurut pengunjung sangat besar antusias dan pengalaman berkunjung ketempat tersebut sehingga keinginan bercerita ke orang lain dari informasi data juga besar.

5. Pengelolaan Pesona Alam Dusun Sendang Kumitir dalam hal pemasaran sudah berjalan dengan baik meski dengan cara sederhana seperti mulut ke mulut dan brosur serta web yaitu blogspot dan facebook

\section{DAFTAR PUSTAKA}

Anomin, 2010, Statistik Kepariwistaan, Dinas Pariwisata Provinsi Daerah Istimewa Yogyakarta

Anonim, 2011. Statistik Kepariwisataan, Dinas Pariwisata Propinsi Daerah Istimewa Yogyakarta

Hadari Nawawi. 2000 : Manajemen Strategik Organisasi Non Profit Bidang Pemerintah . Yogyakarta. Gajah Mada University Press

.Harper, Boyd. W. Et.al.2000. Manajemen Pemasaran Suatu Pendekatan Strategis Dengan Orientasi Global. Jilid I Dan II Edisi I. Erlangga .Jakarta

Kotler, Philip dan Gary Armstrong, 2009. Principles of Marketing, A global perspective. Prentice Hall, Singapore and Malaysia

Muljadi, Arief (2006) : Pokok-Pokok \& Ikhtisar Manajemen Stratejik. Perencanaan dan Manajemen Kinerja, Prestasi Pustaka, Jakarta

Nyoman S. Pendit, 2006. Ilmu Pariwisata, PT.Pradnya Paramita, Jakarta

Nyoman Sudiarta, dkk. Jurnal Perhotelan dan Pariwisata. Januari 2014. Vol. 4 No. 1 hal 2

Oka A yoeti, 2009, Pariwisata Budaya, PT.Pradnya Paramita, Jakarta

Suwantoro, Gamal.1997. Dasar-dasar Pariwisata, Andi Jakarta

Sumarni .2002: Dasar-Dasar Manajemen Pemasaran. Erlangga. Jakarta

Wahyudi, Agustinus Sri. 1996, Manajemen Strategik (Pengantar Proses Berpikir Strategik), Binarupa Aklsara. Jakarta.

Wardiyanta, 2006. Metode Penelitian Pariwisata, CV. Andi. Offset, Yogyakarta 